\title{
Water quality effects on stability and phytotox- icity of picloram and clopyralid
}

\author{
S.G. WHISENANT AND R.W. BOVEY
}

Authors are associate professor, Department of Rangeland Ecology and Management, Texas A\&M University, College Station 77843-2126; and research agronomist, USDA, ARS, Department of Rangeland Ecology and Management, Texas A\&M University, College Station 77843-2126.

\begin{abstract}
Water quality effects on stability of picloram (4-amino-3,5,6tricloro-2-pyridinecarboxylic acid) and clopyralid (3,6-dichloro-2pyridinecarboxylic acid) were evaluated by determining their concentrations in spray mixtures 0,48 , and 168 hours after mixing. Gas chromatography was used to evaluate picloram and clopyralid concentrations in spray solutions mixed with different water sources or buffered water solutions. At 168 hours picloram concentrations in water from La Copita and Midland, Texas, were 11 and $12 \%$ lower than at 0 -hour and 5 and $6 \%$ lower than picloram concentrations in distilled water at 168 hours. Water quality effects on phytotoxicity to honey mesquite (Prosopis glandulosa) were evaluated at 0 and 168 hours after mixing the spray solution. Water quality had no effect on clopyralid phytotoxicity to honey mesquite at either 0 or 168 hours after mixing. Phytotoxicity to honey mesquite was reduced $42 \%$ when picloram mixtures were used 168 hours after mixing with water from La Copita. This indicates the potential for reduced phytotoxicity from picloram when prepared spray solutions are not used for $\mathbf{7}$ days.
\end{abstract}

Key Words: Prosopis glandulosa, herbicide, honey mesquite, herbicide carrier, water hardness

Researchers and commercial applicators have long suspected that water quality may affect phytotoxicity of herbicides used for honey mesquite (Prosopis glandulosa Torr.) control. Some com-

Published with the approval of the Director, Texas Agricultural Experiment Station as TA-30334,

Manuscript accepted 15 Aug. 1992. mercial herbicide applicators avoid using water from certain areas, under the assumption that it adversely affects phytotoxicity. Alkaline or hard water is most often implicated as reducing phytotoxicity. Hard water occurs in many areas of Texas where water for aerial application of herbicides comes from groundwater wells. This water hardness is primarily due to calcium and magnesium salts and total hardness may exceed $250 \mathrm{mg} \mathrm{liter}^{-1}$. Water used for rangeland spraying often has sodium and calcium contents exceeding $450 \mathrm{mg} \mathrm{liter}^{-1}$ and $110 \mathrm{mg} \mathrm{liter}^{-1}$, respectively.

Reduced phytotoxicity may result from structural changes in the herbicide or from reduced absorption of herbicide into the foliage. Reduced phytotoxicity is thought to be more severe when spray solutions are mixed several days prior to application. This commonly occurs when weather conditions halt spraying operations after the spray solution is mixed.

Herbicides may form insoluble salts and precipitate out of solution or form insoluble salts in plant cells which fail to translocate. Most auxin-type herbicides are absorbed best as weak acids in undissolved form, but may form insoluble salts that have difficulty penetrating the cuticle or translocating. Sorption of weakly acidic auxins by cuticular membranes is reduced in alkaline spray solutions (Schönherr 1976, Riederer and Schöherr 1984, Bukovac et al. 1990). Uptake of 2,4,5-T (2,4,5-trichlorophenoxy acetic acid) by honey mesquite and live oak (Quercus virginiana Mill.) decreases in alkaline spray solutions (Baur et al. 1971, 1974). The activity of 2,4-D (2,4-dichlorophenoxy acetic acid) is also reduced in alkaline solutions (Blackman and Robertson-Cuninghame 1953, Orgell and Weintraub 1957, Szabo and Bucholtz 1961, Wedding and 
Erickson 1957). Glyphosate [N-(phosphonomethyl)glycine] was less phytotoxic when applied in $10-\mathrm{mM}$ solutions of $\mathrm{CaCl}_{2}, \mathrm{FeSO}_{4}$, $\mathrm{Fe}_{2}\left(\mathrm{SO}_{4}\right)_{3}, \mathrm{MgSO}_{4}, \mathrm{NaHCO}_{3}, \mathrm{Na}_{2} \mathrm{CO}_{3}$, and $\mathrm{ZnSO}_{4}$ than when applied in distilled water.

Picloram (4-amino-3,5,6-tricloro-2-pyridinecarboxylic acid) and clopyralid (3,6-dichloro-2-pyridinecarboxylic acid) are weakly acidic auxins regularly used for honey mesquite control in areas with alkaline and hard water. Despite the lack of data indicating clopyralid and picloram activity is adversely affected by water quality, commercial adjuvants are marketed to counteract detrimental properties of alkaline waters. The extent of water quality impacts on efficacy of rangeland herbicide applications is largely unknown. The objectives of this research were to determine the effect of water quality on the stability and phytotoxicity of clopyralid and picloram when used for control of honey mesquite.

\section{Materials and Methods}

\section{Plant Material}

Honey mesquite plants were grown from seed in the greenhouse for 12 weeks in pots (12.7-cm diameter by $12.7-\mathrm{cm}$ deep) containing a mixture of Bleiblerbille clay (fine, montmorillonitic Udic Pellustert), sand, and peat moss $(1: 1: 1, \mathrm{v} / \mathrm{v} / \mathrm{v})$ from February to May 1990. Two plants were grown per pot and each had single woody stems averaging $36 \mathrm{~cm}$ tall with an average of 15 to 17 leaves per plant. Pots were randomly arranged in the greenhouse, watered daily to soil saturation, and a commercial fertilizer (13-13-13) applied at $0.85 \mathrm{~g}$ per pot. Daytime temperature was 25 to $30^{\circ} \mathrm{C}$, and night temperature was 20 to $25^{\circ} \mathrm{C}$. Day length averaged 12 hours with $775 \mu \mathrm{E} \mathrm{m}^{-2} \mathrm{~s}^{-1}$ photosynthetically active radiation (PAR) at midday.

\section{Comparison of Water Sources}

Water samples were collected in April 1990 from 3 locations in Texas [Brazos (College Station), Midland (Midland), and Jim Wells (La Copita) counties]. Samples were stored in the dark at $5^{\circ}$ $\mathrm{C}$ until used. Mesquite plants were treated with the monoethanolamine salt of clopyralid and the potassium salt of picloram applied to the foliage at $0.6 \mathrm{~kg} \mathrm{ae} \mathrm{ha}^{-1}$ at 0,48 , and 168 hours after mixing. Applications were in 93 liters ha ${ }^{-1}$ s using the various water sources and buffered solutions. Samples were tested for bicarbonate, boron, calcium, carbonate, iron, magnesium, nitrate, phosphate, potassium, sodium, sulfate, and zinc content.

\section{Prepared Ion Solutions}

Using the results of the water analyses as a guide, aqueous solutions of $\mathrm{CaCl}_{2}, \mathrm{MgSO}_{4}$, and $\mathrm{Na}_{2} \mathrm{CO}_{3}$ were prepared at concentrations of $10 \mathrm{mM}$ and used to prepare additional spray mixtures. Foliar sprays of clopyralid or picloram were applied at $0.6 \mathrm{~kg} \mathrm{ha}^{-1}$ in 93 liters ha $\mathrm{ha}^{-1}$ of water carrier in a laboratory spray chamber (Bouse and Bovey 1967) to pots containing honey mesquite in April and May 1990.

\section{Analytical Procedures}

Clopyralid and picloram were extracted and analyzed from slight modification of published methods (Leitch and Fagg 1985, Cotterill 1978). The gas chromatograph was equipped with an electron capture detector $\left({ }^{63} \mathrm{Ni}\right)$ operated at $300^{\circ} \mathrm{C}$. The injector port temperature was $280^{\circ} \mathrm{C}$ and column temperatures were $140^{\circ}$ $\mathrm{C}$ for clopyralid and $180^{\circ} \mathrm{C}$ for picloram. The $2-\mathrm{m}$ column was packed with $3 \%$ OV210 on 80 to 100 mesh Supelcoport. Herbicide concentrations were determined by comparing peak areas with those of prepared standards. Clopyralid and picloram recovery averaged over $90 \%$ and they were easily detected to $0.05 \mathrm{mg} \mathrm{liter}^{-1}$ of water.

\section{Treatment Analysis}

Sixty days after spraying, the response of treated plants to picloram or clopyralid sprays mixed with the various water samples were evaluated by estimating the percentage of dead stem tissue on each plant. Plants with $100 \%$ dead stem tissue and no resprouts were considered dead. Six replications with 2 plants/replicate were used in a randomized block design. Data were subjected to analysis of variance and means were compared with Fisher's protected LSD at the 0.05 level of significance. The experiments were repeated and data pooled for statistical analysis.

\section{Results and Discussion}

Ion concentration varied greatly between water sources, with Midland water containing the highest concentrations of calcium, magnesium, potassium, sodium, and sulfate and the lowest concentrations of bicarbonate and carbonate (Table 1). College Station water contained the highest bicarbonate concentrations and

Table 1. Ion concentrations in water used to evaluate the effects of water quality on picloram and clopyralid stability and phytotoxicity.

\begin{tabular}{lccr}
\hline \hline Ions & College Station & La Copita & Midland \\
\hline & & $(\mathrm{mg} /$ liter) & \\
Boron & 0.25 & 0.84 & 0.32 \\
Calcium & 3.30 & 19.40 & 114.00 \\
Iron & 0.00 & 0.00 & 0.01 \\
Magnesium & 0.10 & 10.00 & 88.00 \\
Potassium & 1.99 & 7.88 & 17.90 \\
Sodium & 195.00 & 288.00 & 468.00 \\
Zinc & 0.01 & 0.01 & 0.01 \\
Total Cations & 200.40 & 325.00 & 688.10 \\
Bicarbonate & 407.35 & 289.85 & 94.00 \\
Carbonate & 11.56 & 15.41 & $<8.30$ \\
Chloride & 46.00 & 224.00 & 675.00 \\
Nitrate & 0.48 & 8.28 & 0.72 \\
Phosphorus & 0.10 & 0.10 & 0.10 \\
Sulfate & 18.72 & 109.20 & 583.44 \\
Total Anions & 483.60 & 638.5 & 1352.40 \\
& & & \\
Hardness (mg ${ }^{-1}$ ) & 3.42 & 35.76 & 258.69 \\
Specific conduc- & 9.75 & 18.50 & 42.90 \\
$\quad$ tivity (s m $^{-1}$ ) & & & \\
\hline
\end{tabular}

the lowest boron, calcium, magnesium, potassium, sodium, and sulfate concentrations. La Copita water contained intermediate concentrations of most ions, but had the highest carbonate and nitrate levels. The highest $\mathrm{pH}$ occurred in water from La Copita and College Station.

Analyses of herbicide solutions at 0 -hours after mixing were included as a control or reference standard for the evaluation of changes in stability and phytotoxicity over time. Herbicide solutions mixed in distilled water also served as a control or reference standard against which we compared solutions 168 hours after mixing and those mixed in other water types. Each combination of water type-time concentration was compared against distilled water at the same time and against the same water source at other time periods. We believed the most conservative approach to identifying water-time combinations that may cause problems was to consider only those concentrations (in Table 2) differing from distilled water at the same post-mix time and differing from the same water type at other post-mix times.

Chromatographic analyses of herbicide solutions detected no differences in concentrations of either picloram or clopyralid immediately after mixing (Table 2). This indicated the herbicide solutions were similarly mixed and not immediately affected by water quality. Additional chromatographic analyses found that distilled water had no effect on either picloram or clopyralid stability after 168 hours (Table 2). Clopyralid solutions were generally 
Table 2. Concentrations of picloram and clopyralid at 3 times after mixing in various water solutions.

\begin{tabular}{|c|c|c|c|c|c|}
\hline \multirow{2}{*}{$\begin{array}{l}\text { Herbicide } \\
\text { Water type }\end{array}$} & \multirow[b]{2}{*}{$\mathrm{pH}$} & \multicolumn{3}{|c|}{$\begin{array}{c}\text { Time after mixing } \\
\text { (hour) }\end{array}$} & \multirow[b]{2}{*}{$\operatorname{LSD}(0.05)$} \\
\hline & & 0 & 48 & 168 & \\
\hline & \multicolumn{5}{|c|}{ (mg/liter) } \\
\hline Picloram & & & & & \\
\hline Distilled water & 6.4 & 164.2 & 160.1 & 153.1 & NS \\
\hline College Station & 8.5 & 164.7 & 167.2 & 147.1 & 7.9 \\
\hline La Copita & 8.6 & 163.8 & 161.1 & 145.6 & 9.2 \\
\hline Midland & 8.2 & 164.0 & 161.7 & 143.8 & 11.6 \\
\hline $\mathrm{CaCl}_{2}$ buffer & 6.3 & 160.6 & 143.3 & 150.7 & NS \\
\hline $\mathrm{MgSO}_{4}\left(7 \mathrm{H}_{2} \mathrm{O}\right)$ buffer & 6.3 & 153.4 & 154.6 & 154.5 & NS \\
\hline $\mathrm{Na}_{2} \mathrm{CO}_{3}$ buffer & 11.0 & 161.3 & 144.7 & 161.2 & NS \\
\hline $\operatorname{LSD}(0.05)$ & & NS & 10.8 & 7.2 & \\
\hline \multicolumn{6}{|l|}{ Clopyralid } \\
\hline Distilled water & 6.4 & 147.9 & 150.3 & 148.3 & NS \\
\hline College Station & 8.5 & 151.3 & 155.0 & 145.1 & 7.9 \\
\hline La Copita & 8.6 & 148.1 & 147.2 & 147.1 & NS \\
\hline Midland & 8.2 & 146.5 & 152.6 & 148.0 & NS \\
\hline $\mathrm{CaCl}_{2}$ buffer & 6.3 & 148.1 & 148.5 & 152.2 & NS \\
\hline $\mathrm{MgSO}_{4}\left(7 \mathrm{H}_{2} \mathrm{O}\right)$ buffer & 6.3 & 151.1 & 151.3 & 150.7 & NS \\
\hline $\mathrm{Na}_{2} \mathrm{CO}_{3}$ buffer & 11.0 & 145.8 & 149.7 & 149.1 & NS \\
\hline $\operatorname{LSD}(0.05)$ & & NS & 5.5 & NS & \\
\hline
\end{tabular}

stable in all water sources and buffered solutions over the 168 hours evaluation (Table 2). Clopyralid was only reduced in the College Station water 168 hours after mixing, but even this was not significantly different from clopyralid concentrations in distilled water solutions at the same time period (Table 2). At 168 hours after mixing, only the herbicide solutions using La Copita and Midland water sources had lower picloram concentrations than that from 0 -hour ( 11 and $12 \%$ reductions, respectively) and from distilled water ( 5 and $6 \%$ reductions, repsectively) (Table 2 ).

Phytotoxicity of clopyralid and picloram were not affected by water quality when applied immediately after mixing, nor were they affected after 168 hours when mixed with distilled water (Table 3). After 168 hours, mesquite stemkill was significantly

Table 3. Stem kill of honey mesquite grown in the greenhouse following application of $0.6 \mathrm{~kg} \mathrm{ha}^{-1}$ picloram or clopyralid in various water solutions.

\begin{tabular}{lccc}
\hline \hline \multirow{2}{*}{$\begin{array}{l}\text { Herbicide } \\
\text { Water source }\end{array}$} & \multicolumn{2}{c}{ Time after mixing (hours) } & \\
\cline { 2 - 3 } & 0 & 168 & \\
\hline Picloram & \multicolumn{2}{c}{ (\% stemkill) } & LSD (0.05) \\
Distilled & 53 & 61 & NS \\
College Station & 43 & 56 & NS \\
La Copita & 57 & 33 & Significant \\
Midland & 40 & 46 & NS \\
LSD (0.05) & $N S$ & 23 & \\
Clopyralid & & & \\
Distilled & 28 & 21 & NS \\
College Station & 32 & 32 & NS \\
La Copita & 15 & 24 & NS \\
Midland & 35 & 22 & NS \\
LSD (0.05) & $N S$ & NS & \\
\hline
\end{tabular}

reduced when picloram was mixed in water from La Copita. Phytotoxicity of clopyralid was not affected by the variation in water quality used in this study (Table 3 ). Picloram phytotoxicity to honey mesquite was reduced by $42 \%, 168$ hours following mixing with water from La Copita (Table 3).

Clopyralid stability and phytotoxicity were not reduced by water types studied in these experiments. The La Copita and Midland water types reduced picloram stability 168 hours after mixing. Attributes of water quality which may have reduced picloram stability and phytotoxicity (La Copita only) are not completely clear. The La Copita and Midland waters contained more $\mathrm{Ca}, \mathrm{Mg}, \mathrm{K}, \mathrm{Na}$, and total hardness than the College Station water and had greater specific conductivities (Table 1). Hard or alkaline water might decrease picloram phytotoxicity by forming insoluble salts that (1) precipitate out of solution; (2) do not penetrate the cuticle; or (3) do not translocate. In this study, reduced phytotoxicity was generally associated with lower picloram concentrations in the spray solution, suggesting the formation of insoluble salts that might have precipitated picloram out of solution, but those data are inconclusive. However, none of the buffered solutions reduced picloram concentrations after 168 hours (Table 2).

Water quality affected picloram efficacy when herbicide solutions were mixed several days prior to application. When these results became evident after the first experiments, we repeated the entire study. Data presented are pooled from both experiments. The results of the first and second application of both the stability and phytotoxicity experiments were not significantly different, indicating the observed pattern of reduced phytotoxicity was real rather than the result of random or experimental error.

This research indicates the potential for reduced picloram activity on honey mesquite when spray solutions are mixed 7 days prior to application. This usually occurs when environmental conditions (such as excessive wind speed or temperature) delay application. We were unable to determine the water quality factors causing the problems. No phytotoxicity reductions should be anticipated unless the herbicide solution is mixed several days prior to application.

\section{Literature Cited}

Baur, J.R., R.W. Bovey, R.D. Baker, and I. Rile. 1971. Absorption and penetration of picloram and 2,4,5-T into detached live oak leaves. Weed Sci. 19:138-141.

Baur, J.R., R.W. Bovey, and I. Rile. 1974. Effect of $\mathrm{pH}$ on foliar uptake of 2,4,5-T C'14. Weed Sci. 22:481-486.

Blackman, G.E., and R.C. Robertson-Cuninghame. 1953. The influence of $\mathrm{pH}$ on the phytotoxicity of 2,4-dichlorophenoxyacetic acid to Lemna minor. New Phytol. 52:71-75.

Bouse, L.R., and R.W. Bovey. 1967. A laboratory sprayer for potted plants. Weeds 15:89-91.

Buhler, D.D., and O.C. Burnside. 1983. Effect of water quality, carrier volume, and acid or glyphosate phytotoxicity. Weed Sci. 31:163-169.

Bukovac, M.J., P.D. Petracek, R.G. Fader, and R.M. Morse. 1990. Sorption of organic compounds by plant cuticles. Weed Sci. 38:289-298.

Cotterill, E.G. 1978. Determination of 3,6-dichloropicolinic acid residues in soil by gas chromatography of the 1-butyl ester. Bull. Environ. Contamin. Toxicol. 15:471-474.

Fullilove, H.M. 1968. Herbicides and fertilizer combination found to lower yields. Crop and Soils 20:29.

Leitch, C., and P. Fagg. 1985. Clopyralid herbicide residues in streamwater after aerial spraying of a Pinus radiata plantation. N. Z. J. Forestry Sci. 15:195-206.

Orgell, W.H., and R.T. Weintraub. 1957. Influence of some ions on foliar absorption of 2,4-D. Bot. Gaz. 119:88-97.

Richardson, R.G. 1977. A review of foliar absorption and translocation of 2,4-D and 2,4,5-T. Weed Res. 17:259-272.

Riederer, M., and J. Schönherr. 1984. Accumulation and transport of (2,4-dichlorophenoxy) acetic acid in plant cuticles: I. Sorption in the cuticular membrane and its components. Ecotox. Environ. Safety 8:236-247.

Schönherr, J. 1976. Napthaleneacetic acid permeability of citrus leaf cuticle. Cuticle. Biochem. Physiol. Pflanz. 170:309-319.

Szabo, S.S., and K.P. Bucholtz. 1961. Penetration of living and non-living surfaces by 2,4-D as influenced by ionic additives. Weeds 9:177-184.

Szabo, S.S., and K.P. Bucholtz. 1961. Penetration of living and non-living surfaces by 2-4D as influenced by ionic additives. Weeds 9:177-184.

Wedding, R.T., and L.C. Erickson. 1957. The role of $\mathrm{pH}$ in the permeability of chlorella to 2,4-D. Plant Physiol. 32:503-512.

Wilson, B.J., and R.K. Nishimoto. 1975. Ammonium sulfate enhancement of picloram activity and absorption. Weed Sci. 23:289-296. 